\title{
Modeling and Simulation of Solar Photovoltaic Renewable Energy Sources Power Generation System for MGs and Loss of Mains Detection
}

\author{
Mogaka L. Ong' ondo ${ }^{*}$, Nyakoe G. Nyauma² and Michael Juma Saulo ${ }^{3}$ \\ 1 Department of Electrical and Electronics Engineering, Pan African University of Science \\ Technology and Innovation, P.O. Box 62000 - 00200, Juja, Kenya; ${ }^{2}$ Department of Electrical and \\ Electronic Engineering, Jomo Kenyatta University of Agriculture and Technology, P.O. Box P.O. \\ Box 62000-00200, Juja, Kenya; ${ }^{3}$ Department of Electrical and Electronics Engineering, Technical \\ University of Mombasa, P.O. Box 90420 - 80100, Mombasa, Kenya \\ *Corresponding author: mogaka.lucas@gmail.com
}

\begin{abstract}
$\mathrm{P}$ ower generation from Renewable Energy Sources (RESs) is steadily increasing due to a number of reasons. These include government subsidies on these RESs, improvement in technology in their manufacture and efforts to reduce greenhouse gas emissions. However, these RESs have associated challenges like intermittency in power generation hence unreliable power supply. Solar PV is gaining popularity as compared to other RESs due to its unique advantages in grid connected applications. It is therefore important to carry out accurate design and enough simulations on its dynamic behavior before actual installation at any given location using local environmental parameters. This paper discusses the detailed modelling, simulation and dynamic behavior of solar PV power generation systems for MG applications using Matlab/Simulink platform.
\end{abstract}

Key Words: Solar PV, Modeling, Renewable energy sources, Loss of mains detection

\section{Introduction}

The increasing world population calls for a proportional increase in power generation and supply. In order to keep in pace with the increasing power demand, generation from renewable energy sources (RESs) like solar PV are intensively being used as compared to conventional sources of electrical power. This is due to the depletion of the fossil fuel reserves, their environmental friendliness and favorable government policies (Shahzada, 2018). Additionally, solar PV is simple to deploy, needs minimal maintenance and it is available in abundance in most parts of the world. Edmund Becquerel was the first physicist to come up with the concept that electricity is generated when certain materials are exposed to sunlight in the year 1839. However, little research was done on this area until 1905 when Albert Einstein gave a more detailed explanation on light and photoelectric effect. It states that electrons flow when photons of sunlight hits a metal surface. This is the basis of power generation from PV power generation system. The Bell laboratories manufactured the first PV module in the year 1954.

Among the many RESs, photovoltaics is the most sustainable RES because it is widely and freely available in most places as compared to other sources, needs little operation and maintenance costs since it does not have moving part and does not have negative environmental impact (Pandiarajan \& Ranganath, 2011). Generally, the output of a PV generation system depends on the temperature of the solar cell and the solar insolation. Now that the output of the PV modules have non-linear behavior, they have to be designed, modelled and simulated for maximum power point tracking (MPPT) before being used in the analysis of any power system application.

In this study, a PV power plant is modelled and simulated for applications in MGs and loss of mains detection. The rest of this paper is organized as follows; section II discusses the steps and components of power generation from a PV power plant, section III is the description of the system and

Published: December 2020 
parameters that are used in this study, while IV and $\mathrm{V}$ discuss the results and conclusion of this study, respectively.

\section{Power Generation from PV}

This is the actual process where the solar energy is changed to useful electrical energy by using certain semi-conductor materials. A p-n junction is the essential and fundamental element of a PV cell. This is illustrated in Figure 1 below.

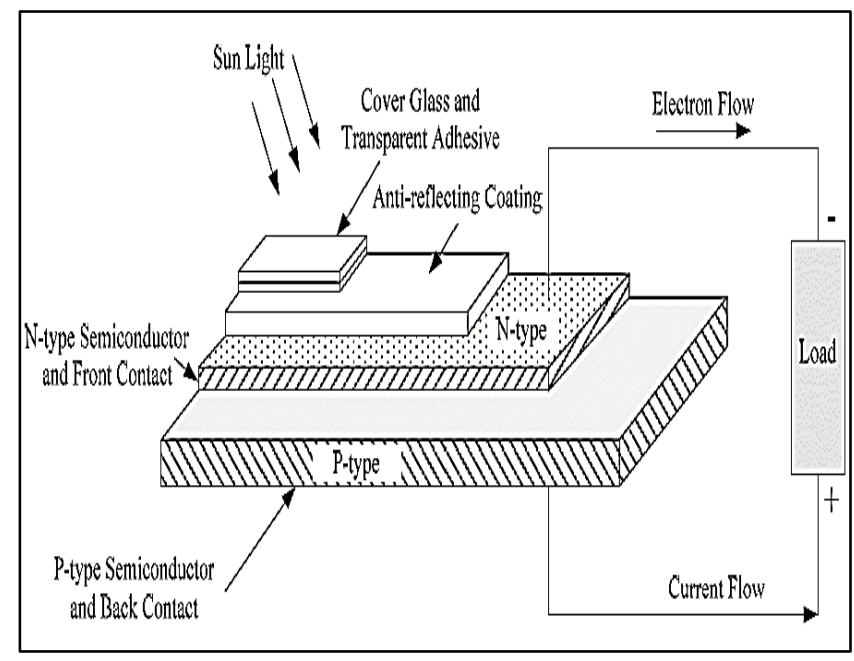

Figure 1. Components of a fundamental PV cell

\section{Photovoltaic Effect}

When the light from the sun falls on this semiconductor material, an electron-hole pairs are created as a result of the transfer of energy from the protons. This creates an electric field at the $p-n$ junction thus separating the electron-hole pairs. The holes are directed to the p-region of the semiconductor material while the electrons move to n-region of the material. These electrons are connected to go through an external circuit where it supplies power to the connected load.

\section{Photovoltaic Cell}

A photovoltaic (PV) cell can be defined in simple terms as a device that is made from a semiconductor material that is used to convert sunlight irradiation at a given temperature to useful electrical energy. The energy conversion efficiency of the solar cells ranges from $30-35 \%$. A PV cell consists of a current source connected in parallel with a diode. The modelling of an equivalent circuit of a PV cell is elaborated by Islam et al., (2013). When operating alone, a cell is able to generate up to 0.4 volts. However, this output varies from time to time depending on the temperature and insolation at that point. A solar cell circuit can be represented in Fig. 2 below.

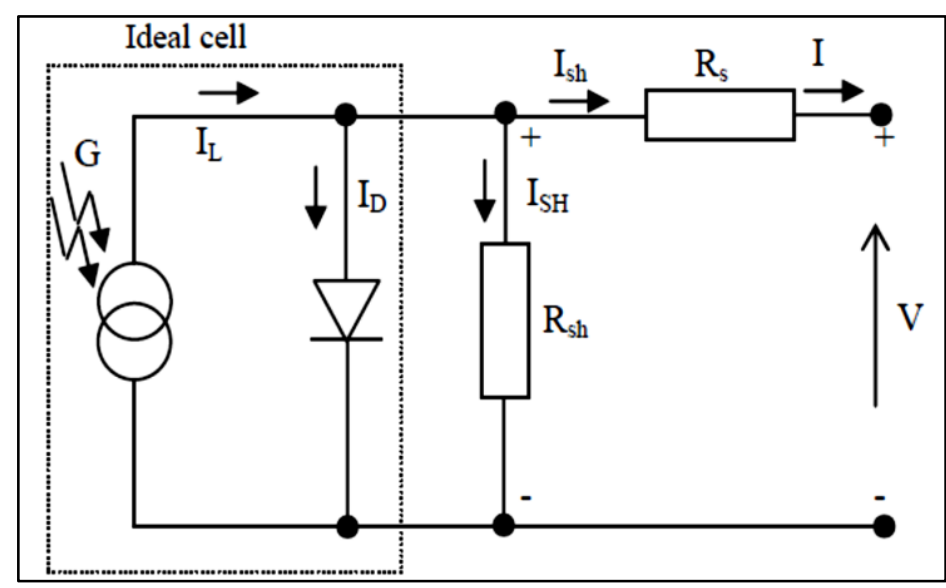

Figure 2. Solar PV cell circuit

In parallel with the source is a shunt resistance $\left(R_{\text {sh }}\right)$, it is a leakage path of the PV current. The expression for the solar cell output current and IV behavior of a PV cell can be given as follows according to Mahajan \& Bhole, (2016);

$$
\begin{aligned}
& I=I_{L}-I_{0}\left(e^{\frac{q\left(V+I R_{S}\right)}{n k T}}-1\right) \\
& I_{L}=I_{L(T 1)}\left(1+K_{0}\left(T-T_{1}\right)\right) \\
& I_{L(T 1)}=\frac{G}{G_{n o m}} * I_{S C(T 1)} \\
& K_{0}=\frac{I_{S C(T 2)}-I_{S C(T 1)}}{T_{2}-T_{1}} \\
& I_{0}=I_{0(T 1)} *\left(\frac{T}{T_{1}}\right)^{\frac{3}{n}} * e^{\frac{-q v_{g}}{n k}} *\left(\frac{1}{T}-\frac{1}{T_{1}}\right) \\
& I_{0(T 1)}=\frac{I_{S C}\left(T_{1}\right)}{e^{\frac{q V_{o c}\left(T_{1}\right)}{n k T_{1}-1}}}
\end{aligned}
$$

Where $V$ is the voltage across the cell terminals, $I$ is the current output of the cell, $T$ the absolute temperature the system is working in, $I_{l}$ the photogenerated current, $K$ the Boltzmann's constant, $q$ the charge, $n$ the diode factor of ideality, $V g$ band 
gap voltage, Isc short circuit current, $G$ radiation in $\mathrm{W} / \mathrm{m}^{2}, \mathrm{~T}_{1}$ reference temperature, $K_{0}$ temperature coefficient of Isc and $I_{0}$ is the reverse saturation current (Sharandeep et al., 2016).

When this method of power generation by converting the solar radiation to electricity by using photovoltaic cells are arranged in series and parallel, they form an array. The DC power produced is stepped up and converted to alternating current using appropriate converters. Figure 3 below shows an arrangement of power generation using PV cells.

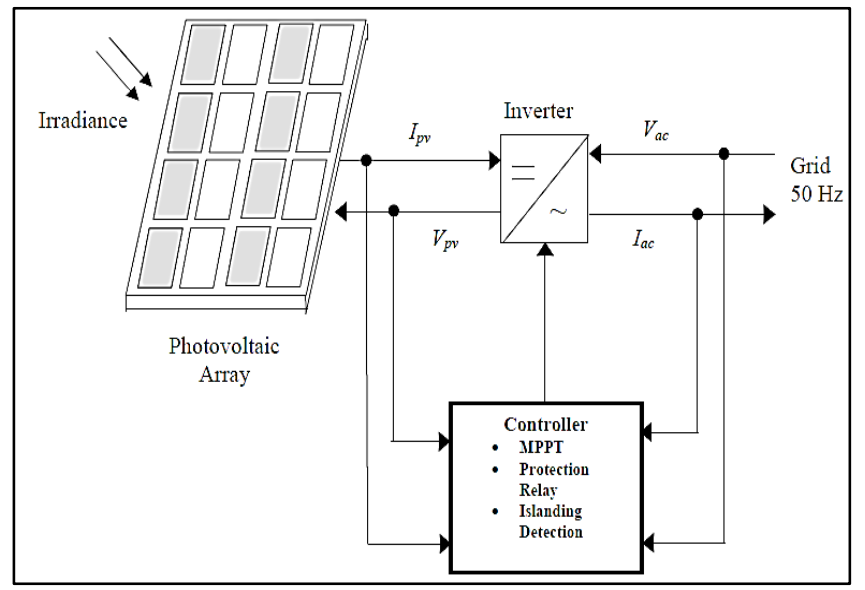

Figure 3. Grid connected PV generation arrangement

\section{The PV Module}

To increase the output, the PV cells are connected in parallel and in series. This series and parallel connection of cells forms a PV module. One PV module consists of a combination of cells ranging from 36 to 76. The series connection of PV cells increases voltage generation while parallel connection increases current generated.

\section{An Array of PV Modules}

When a number of PV modules are connected in series and parallel, they form a PV array. This is done so as to increase the output as per the load requirement and grid connection. When connecting modules into arrays, one starts with the serial connection till the desired voltage is achieved before connecting those strings in parallel to attain the required currents. This is illustrated in the Figure 4 below.

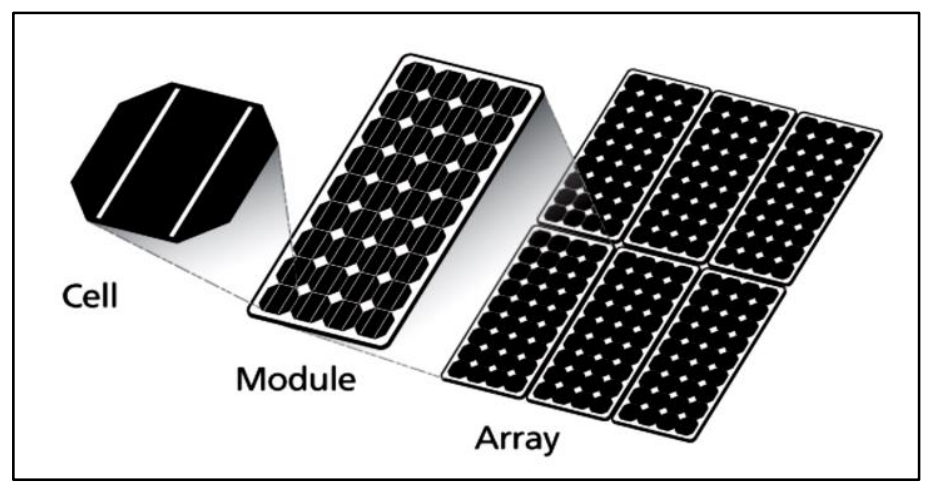

Figure 4. PV cell. Module and Array connection

The corresponding sketch of a PV module is as shown in Figure 5 below.

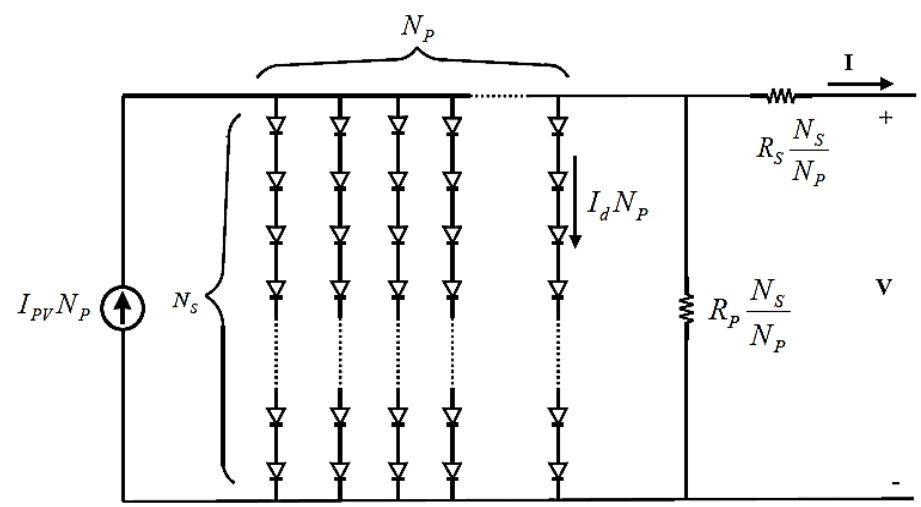

Figure 5. PV module representation

This is mathematically expressed by the following equation:

$$
\begin{aligned}
I=I_{P V} N_{P}-I_{0} N_{P} & {\left[e^{\left[\frac{V+I R_{S}\left[\frac{N_{S}}{N_{P}}\right]}{a V_{T} N_{S}}\right]}-1\right] } \\
& -\left[\frac{V+I R_{S}\left(\frac{N_{S}}{N_{P}}\right)}{R_{P}\left(\frac{N_{S}}{N_{P}}\right)}\right](v i i)
\end{aligned}
$$

Where $N p$ is the number of cells connected in parallel and $N s$ is the number of cells connected in series. The short circuit current $I_{s c}$ and open circuit voltage $V_{o c}$ are the two main parameters used to determine the performance of a PV cell. These are graphically shown in Figure 6 below. 

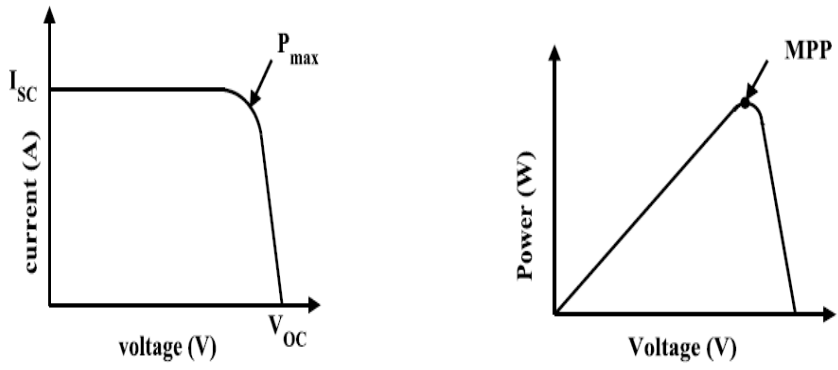

Figure 6. I-V and P-V characteristics

\section{PV Maximum Power Point Tracking}

Now that the solar cell output varies based on weather insolation and temperature, there is need to look for a way of maximizing the harvest of the solar insolation in any given area. The point on the $\mathrm{I}-\mathrm{V}$ and $\mathrm{P}-\mathrm{V}$ curve where a maximum power can be generated from a cell at a higher efficiency is known as the maximum power point (MPP). This point can be arrived at through appropriate algorithms or calculations. One of the algorithms that is mostly used in finding the MPPT is the Perturb and Observe method. It is economical for small system, simple and less complex and can be applied so easily. Its flow chart is shown in Figure 7 below as according to Elsherbiny et al., (2016).

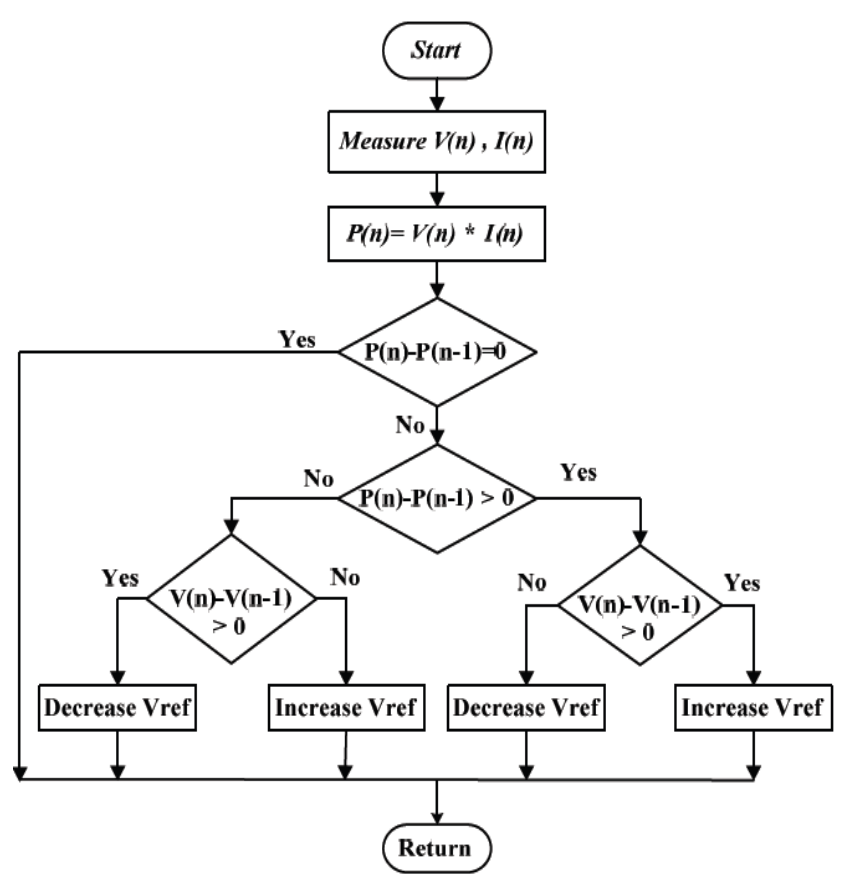

Figure 7. Perturb and observe technique flow chart

A DC-DC converter is used in the evaluation of the MPPT whose duty cycle is used to control the voltage, current and consequently the power of the PV generator in the process of attaining maximum output possible (Tripathi \& Badoni, 2013).

\section{DC-DC Boost Converter}

In simple terms, converters can be referred as electronic circuits that have switches, inductors and capacitors that are connected in such a way so as to give the required output. Hence, the DC-DC boost converters are used to step up the input voltage to a higher value. This comprises of a combination of diodes, MOSFETS, capacitors and inductors. Fig. 8 below is an illustration of a boost converter.

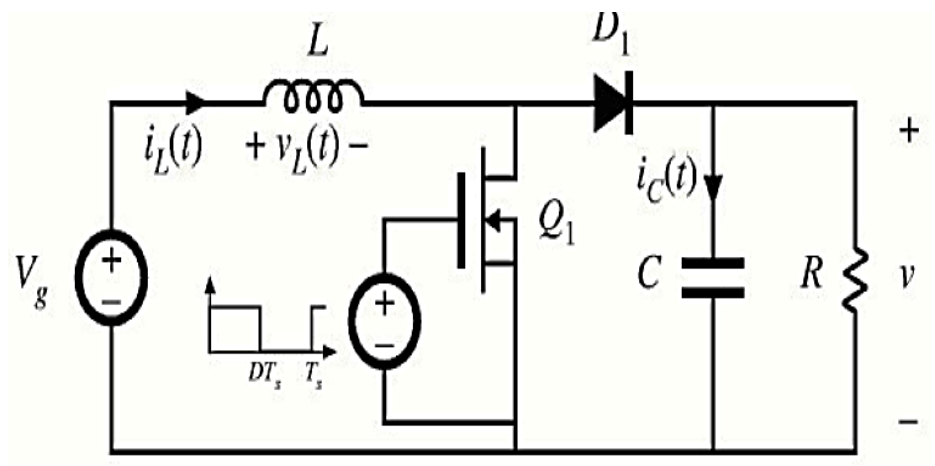

Figure 8. DC-DC boost converter

\section{System Description}

A distribution power grid of $11-\mathrm{kV}$ was modelled. An array of solar PV of $100 \mathrm{~kW}$ working at 1000 $\mathrm{W} / \mathrm{m}^{2}$ irradiance was connected to this grid using a VSC and DC-DC boost converter operating at 5 $\mathrm{kHz}$.

An MPPT of incremental conductance with integral technique was modelled. A perturb and observe $(\mathrm{P} \& \mathrm{O})$ technique was used in this MPPT controller. A 3-level, 3-phase VSC operating at $1980 \mathrm{~Hz}$ frequency that is used to convert the $500 \mathrm{~V}$ DC link voltage to $240 \mathrm{~V} \mathrm{AC}$. A capacitor bank of $10 \mathrm{kvar}$ for removing the harmonics that may be produced by the VSC was incorporated. A 3-phase coupling transformer whose specifications are; $100 \mathrm{kVA}$, $240 / 11 \mathrm{kV}$. An $11 \mathrm{kV}$ utility grid distribution feeder and equivalent transmission system. These system parameters can be summarized in Table 1 below: 
Table 1. System data used in this simulation

\begin{tabular}{|l|c|}
\hline Parameter & Value \\
\hline Rated power & $100 \mathrm{~W}$ \\
\hline Current at maximum power $\left(\mathrm{I}_{\mathrm{mp}}\right)$ & $5.75 \mathrm{~A}$ \\
\hline Voltage at maximum power $\left(\mathrm{V}_{\mathrm{mp}}\right)$ & $54.7 \mathrm{~V}$ \\
\hline Open circuit voltage $\left(\mathrm{V}_{\mathrm{oc}}\right)$ & $64.6 \mathrm{~V}$ \\
\hline Total number of cells in series $\left(\mathrm{N}_{\mathrm{s}}\right)$ & 5 \\
\hline Short circuit current $\left(\mathrm{I}_{\mathrm{sc}}\right)$ & $6.14 \mathrm{~A}$ \\
\hline Total number of cells in parallel $\left(\mathrm{N}_{\mathrm{p}}\right)$ & 64 \\
\hline Irradiation & $1000 \mathrm{~kW} / \mathrm{m}^{2}$ \\
\hline Temperature & $25^{\circ} \mathrm{C}$ \\
\hline
\end{tabular}

\section{Results and Discussion} PV System Model in Simulink

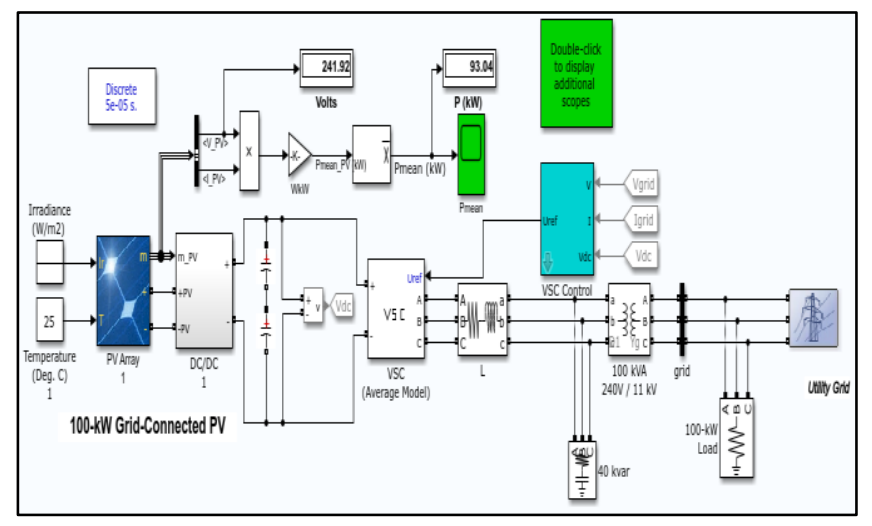

Figure 9. Grid connected PV System model in Simulink

\section{PV Voltage Output}

As can be seen from Figure 10 below, the MPPT regulator is enabled at 0.4 seconds. This then ensures the voltage output is within limits. This is achieved by regulating the duty cycle so as to get maximum power from the system.

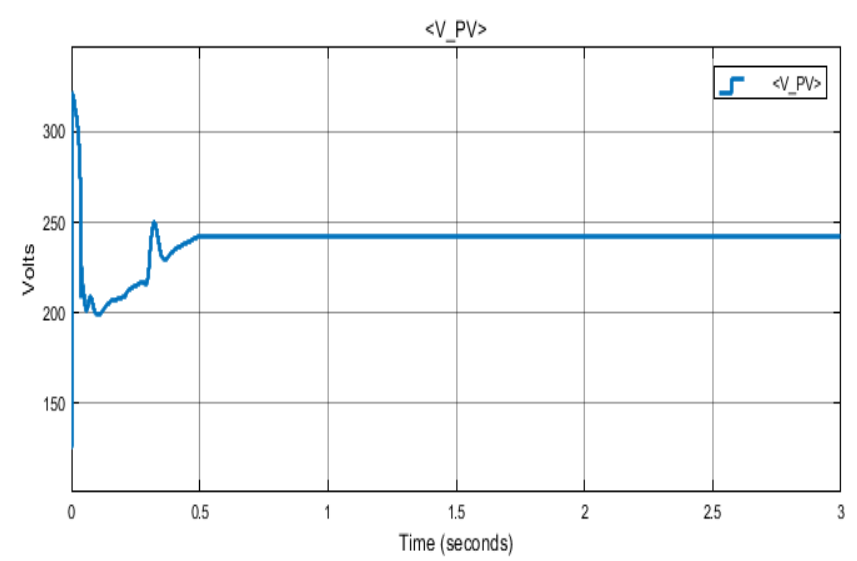

Figure 10. PV voltage output

\section{PV Power Output}

The power output from the simulated system was measured. This is as shown in figure 11 below. As it can be observed, the steady state power output is attained after 0.5 seconds.

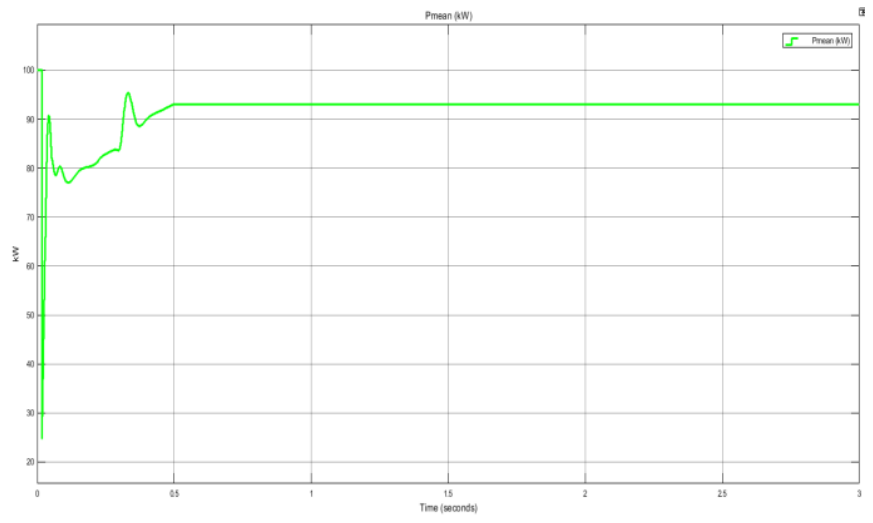

Figure 11. PV mean power

\section{The PV Converter Duty Cycle}

The duty cycle (Fig. 12) is varied by the MPPT system so as to ensure the voltage is maintained within limits in order to generate maximum power possible from the PV generator. The boost converter steps up the DC voltage to around $500 \mathrm{~V}$ DC. It operates at a $5-\mathrm{kHz}$ frequency. From the output below, the PV generator maximum power is achieved when the duty cycle is $\mathrm{D}=0.455$. 


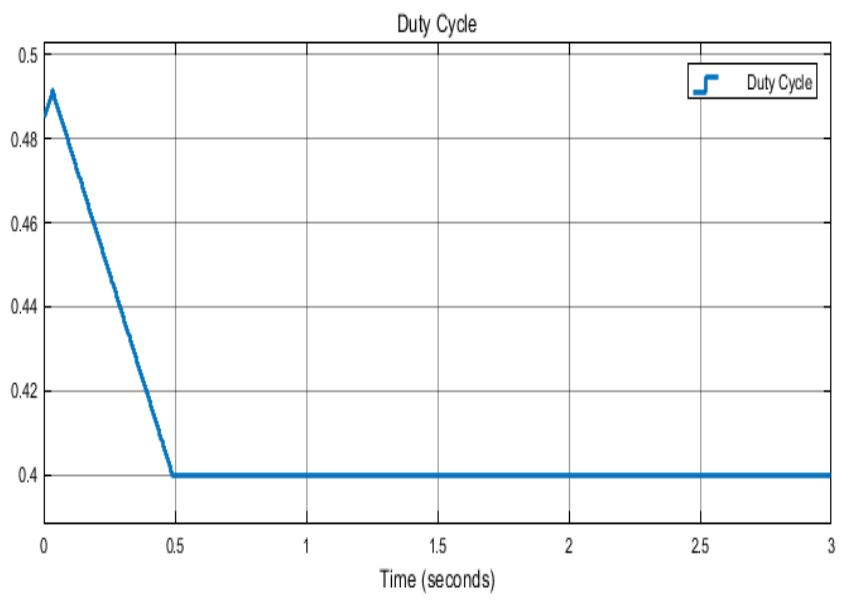

Figure 12. PV converter duty cycle

\section{PV Current Output}

The voltage output from the PV setup was monitored and this is shown in figure 13 below. Since irradiation and temperature parameters were kept constant at $1000 \mathrm{~kW} / \mathrm{m}^{2}$ and $25^{\circ} \mathrm{C}$ respectively, a constant current output of 385A was attained experimental purposes.

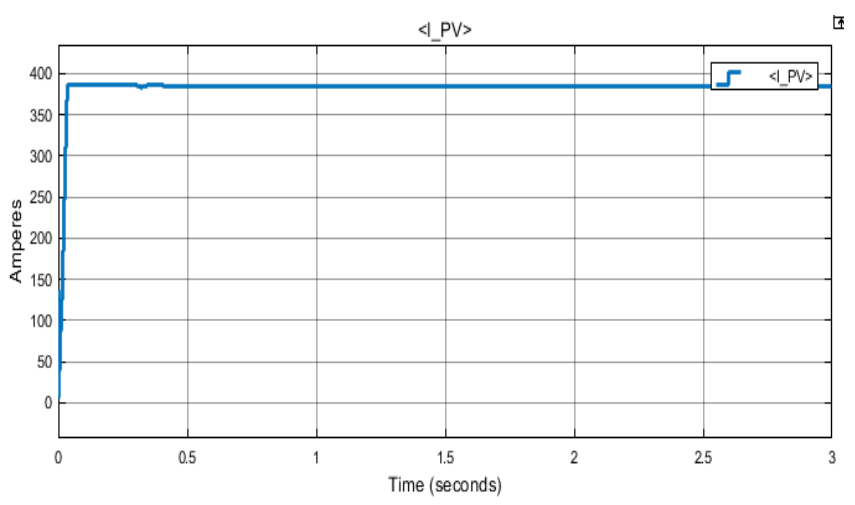

Figure 13. PV current output

\section{PV Diode Current and Vref Output Measurement}

At the cell level, the current produced from each individual diode was measured. This is shown in figure 14 below. This current is combined with other diodes from the cells in parallel and then stepped up to give the PV plant output.

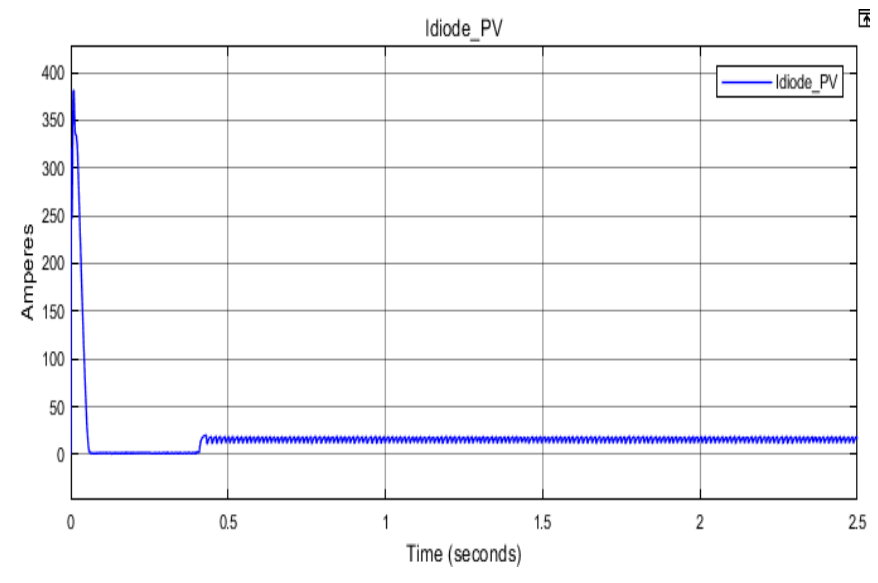

Figure 14. PV diode current output

The system reference voltage is important because it is from which the set output voltage is based. Any variation from this voltage reference can lead to wrong system voltage output. This was monitored and is as shown in figure 15 below.

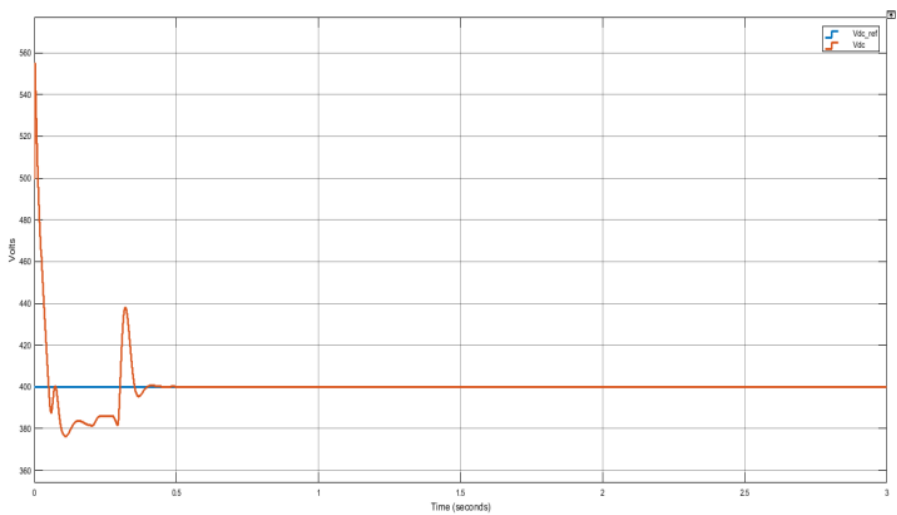

Figure 15. Vref against Vdc

\section{Loss of Mains Simulation}

An intentional loss of mains condition was simulated after 2 seconds by disconnecting the mains. The PV voltage, current and power outputs were measured and are as shown in Fig. $16 a, b, c$ and $d$ below. 

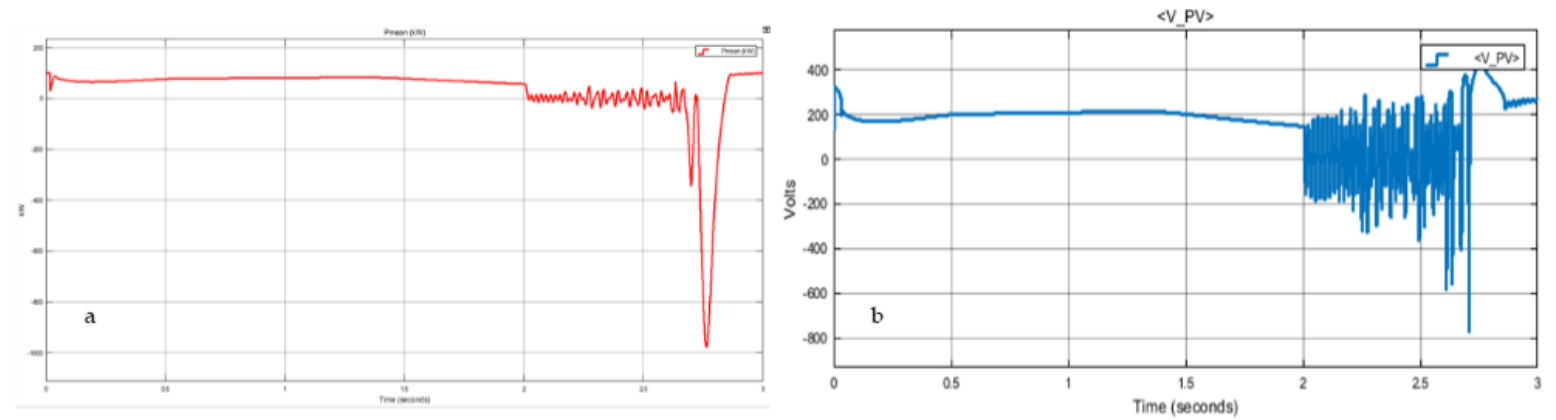

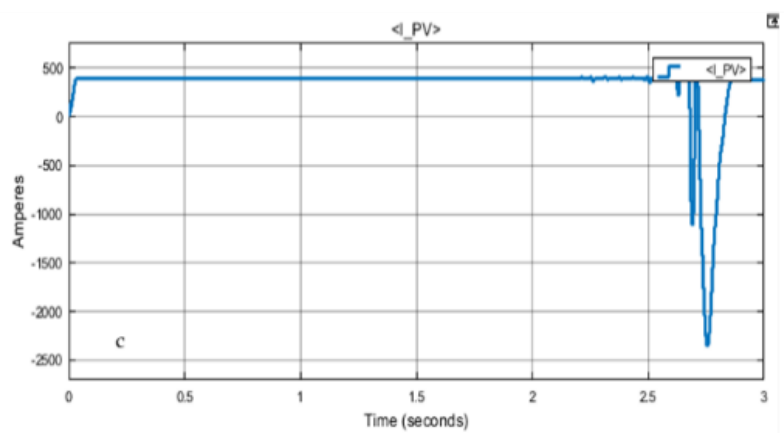

Figure 16. a) PV power output after the fault, b) PV Voltage measurement after the fault, c) PV Current measurement after the fault, and d) Vdc versus Vdc_ref measurement after the fault

As it can be observed from the above voltage, current and power measurement before, during and after islanding simulations, one can easily discern the occurrence of loss of mains through the monitoring of these signals at the point of common coupling.

\section{Conclusion}

This paper has discussed the detailed modelling, simulation and dynamic behavior of solar PV power generation systems for Micro Grid (MG) applications for loss of mains and islanding detection using MATLAB/Simulink platform. It evident that given the actual parameters of any given grid, contingencies can be easily predicted well in advance and hence avoid associated catastrophes and losses. It is therefore recommended for more analysis on islanding condition detection especially in a hybrid of solar PV and wind renewable energy sources.

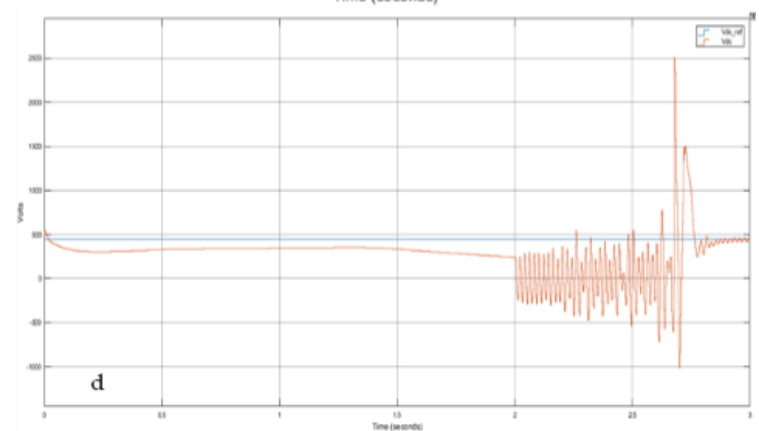

\section{Acknowledgement}

The authors would like to acknowledge Pan African University and African Union for the financial support accorded in form of research funds and final production of this publication.

\section{References}

Shahzada, M., Naeem, N., Shahzad, A. (2018) Energy security for socio-economic and environmental sustainability in Pakistan, Heliyon Elsevier 4(10): 1-21.

Jingying, S., Huailing, W., Xiaoxiao, P., Chun L. (2011). Li A Research for Improved BUCKBOOST Circuit, Electrical Power Systems and Computers 99: 479-485

Elsherbiny, H., Hamdy, A.M.S. \& Amr, R. (2016). Efficiency Improvement for A Hybrid PVWind Energy System. Current Science International 5(3): 256-265

Islam, A. Merabet, A., Beguenane, R. \& Ibrahim, H. (2013). Modeling Solar Photovoltaic Cell and Simulated Performance Analysis of a 250W PV Module. IEEE Electrical Power \& Energy Conference (EPEC) Energy, August 2013: 1-6 Mahajan, P.B. \& Bhole, A.A. (2015). Modeling of Photovoltaic Module. International Research Journal of Engineering and Technology 2(3): 496-500

Pandiarajan, N. \& Ranganath, M. (2011). Mathematical Modeling of Photovoltaic 
Module with Simulink. International Conference on Electrical Energy Systems (ICEES 2011), 3-5 January 2011: 314-319

Sharandeep, S., Parul, G. \& Aditi, G. (2016). Modelling and Simulation of a Multijunction Photovoltaic- Wind Hybrid Power System. International Conference on Advances in Emerging Technology: 14-19

Tripathi, R.S.A., \& Badoni, M. (2013). A MATLABSimulink-Based Solar Photovoltaic Array (SPVA) Module with MPPT. International Conference on Emerging Trends in Communication, Control, Signal Processing E Computing Applications (C2SPCA): 1-6 